\title{
PERBANDINGAN ANTARA RENDAM KAKI AIR HANGAT DAN MASASE KAKI TERHADAP PENURUNAN TEKANAN DARAH PENDERITA HIPERTENSI DI WILAYAH KERJA PUSKESMAS SURADITA KABUPATEN TANGERANG
}

\author{
Riris Andriati, Ayu Selviani Putri \\ STIKes Widya Dharma Husada Tangerang \\ Email : ririsandriati@wdh.ac.id
}

\begin{abstract}
ABSTRAK
Hipertensi suatu keadaan di mana tekanan darah menjadi meningkat melebihi batas normal karena gangguan pada pembuluh darah yang mengakibatkan suplai oksigen dan nutrisi yang dibawa oleh darah terhambat sampai ke jaringan tubuh yang membutuhkannya. Tujuan : Untuk mengetahui adakah Perbandingan antara rendam kaki air hangat dan masase kaki terhadap penurunan tekanan darah penderita hipertensi di Wilayah Kerja Puskesmas Suradita Kabupaten Tangerang.Metode penelitian : desain analitik dengan pendekatan Quasy Experimental Design dengan pendekatan pre dan post test two the group. cara pengambilan data pada penelitian ini dengan cara lembar observasi. Jumlah sampel dalam penelitian ini adalah 50 responden yang dibagi menjadi 2 kelompok, kelompok I Rendam Kaki Air Hangat dan kelompok II Masase Kaki. Teknik analisis data menggunakan uji Wilcoxon Rank Test dengan tingkat signifikasi $\alpha<0,05$. sedangkan untuk mengetahui perbandingan kedua terapi menggunakan uji Mann Whitney Test. Hasil penelitian menunjukkan bahwa : tidak ada perbandingan antara perlakuan rendam kaki air hangat dan Masase Kaki terhadap penurunan tekanan darah, dengan Nilai $\mathrm{P}$ value $=0,831$.
\end{abstract}

Kata Kunci : Rendam kaki air hangat, Masase kaki, Hipertensi.

\begin{abstract}
Hypertension a situation in which blood pressure to rise above normal limits for a on the veins of the who has resulted the supply of oxygen and nutrients carried by obstructed blood to tissues of the body need it. The purpose of this research is to find have comparison between soak the water feet warm and masase the foot against a decrease in blood pressure patients hypertension in the work area of puskesmas suradita kabupaten tangerang. methodology used $s$ a design analytic with the approach quasy experimental design with the approach pre and post test two the group. Way the data on this research by means of sheets of observation.The sample of the in this research was 50 respondents who divided into 2 groups, group I soak the water feet warm and of group II masase feet. Technique analysis data using test wilcoxon rank test with extent of signification $\alpha$ $<0,05$. while to know the likeness of the two therapy use the green whitney test. The research results show that: no comparison between treatment soak the water feet warm and masase the foot against a decrease in blood pressure, with the $p$ value $=0,831$.
\end{abstract}

Keywords: soak the water feet warm, masase feet, hypertension.

\section{LATAR BELAKANG}

Hipertensi ialah suatu keadaan di mana tekanan darah menjadi meningkat melebihi batas normal karena gangguan pada pembuluh darah yang mengakibatkan suplai oksigen dan nutrisi yang dibawa oleh darah terhambat sampai ke jaringan tubuh yang membutuhkannya. Batas tekanan darah normal bervariasi sesuai dengan usia.

$$
\text { Menurut (Masriadi, 2016). }
$$

Menetapkan hipertensi sebagai faktor risiko nomer tiga etiologi kematian di dunia. Hipertensi bertanggung jawab terhadap $62 \%$ timbulnya kasus stroke, $49 \%$ 
timbulnya serangan jantung. Tujuh juta kematian premature tiap tahun disebabkan oleh hipertensi. World health statistics tahun 2012 (WHO) melaporkan sekitar $51 \%$ dari kematian akibat stroke dan $45 \%$ penyakit jantung koroner disebabkan oleh hipertensi. Data WHO menyebutkan bahwa hipertensi menyebabkan 7,5 juta $(12,8 \%)$ kematian diseluruh dunia.

Menurut Hasil Riset Kesehatan Dasar (Riskesdas, 2013) Prevalensi hipertensi di Indonesia berdasarkan hasil pengukuran pada umur $\geq 18$ tahun sebesar 25,8 persen. Jadi cakupan nakes hanya 36,8 persen, sebagian besar $(63,2 \%)$ kasus hipertensi di masyarakat tidak terdiagnosis. Prevalensi Diabetes melitus, hipertiroid, dan hipertensi pada perempuan cenderung lebih tinggi dari pada laki-laki.

Menurut Dinas kesehatan (Dinkes) Kabupaten Tangerang tahun 2014, menurut data kesakitan terdapat 10 besar penyakit yang terdiri dari infeksi saluran pernapasan akut (ISPA) (32\%), Hipertensi (12,2\%), Batuk $(9,9 \%)$, myalgia $(8,3 \%)$, gastritis $(7,7 \%)$, dermatitis $(7,2 \%)$, demam $(6.5 \%)$, dyspepsia (5.9\%), gangguan gigi $(5,3 \%)$, sakit kepala $(4,8 \%)$. Dan Hipertensi berada diposisi kedua (2) dari 10 besar penyakit di kabupaten tangerang.

Menurut Studi Pendahuluan yang saya lakukan di Puskesmas Suradita Kabupaten Tangerang pada tahun 2016 untuk penyakit
Hipertensi esensial (Hipertensi primer) sebesar $6.438(25,74 \%)$ dan menduduki posisi kedua dari 10 besar penyakit yang ada di Puskesmas Suradita Kabupaten Tangerang.

Sebab akibat terjadinya penyakit hipertensi ialah salah satunya terlalu banyak mengkonsumsi garam yang berlebihan. jika penyakit hipertensi tidak segera di tangan akan mengakibatkan penyakit stroke, jantung, gagal ginjal dan kebutaan.

Cara mencegah agar hipertensi tidak menyebabkan komplikasi lebih lanjut maka diperlukan penanganan yang tepat dan efisien. Pengobatan nonfarmakologis merupakan pengobatan tanpa obat-obatan yang diterapkan pada hipertensi. Salah satunya dengan rendam kaki air hangat dan masase kaki.

Merendam Kaki dengan Air Hangat yang bertemperatur $39-40^{\circ} \mathrm{C}$. Secara ilmiah air hangat mempunyai dampak fisiologis bagi tubuh, pertama berdampakpada pembuluh darah dimana hangatnya air membuat sirkulasi darah menjadi lancar, menstabilkan aliran darah dan kerja jantung serta faktor pembebanan didalam air yang akan menguatkan otototot dan ligament yang mempengaruhi sendi tubuh. Merendam kaki dengan air hangat bermanfaat untuk vasodilatasi aliran 
darah sehingga diharapkan dapat mengurangi tekanan darah (Ilkafah, 2016).

Terapi pijat (masase) kaki merupakan tindakan manipulasi otot-otot dan jaringan dalam tubuh dengan tekanan, menggosok, dan vibrasi atau getaran dengan menggunakan sentuhan tangan, jari-jari tangan, sikut, kaki, alat-alat manual atau elektrik untuk memperbaiki kondisi kesehatan (Nurgiwiati, 2015).

Berdasarkan data yang sudah di paparkan peneliti tertarik untuk melakukan penelitian tentang "Perbandingan antara rendam kaki air hangat dan masase kaki terhadap penurunan tekanan darah penderita hipertensi di Wilayah Kerja Puskesmas Suradita Kabupaten Tangerang

\section{METODE PENELITIAN}

Jenis penelitian yang digunakan adalah Komparatif dengan desain penelitian Quasy Experimental Design (eksperimen semu) dengan pendekatan pre dan post test two the group, Kedua kelompok ini akan diberikan perlakuan (kelompok pertama terapi rendam kaki air hangat dengan suhu $39-40^{\circ} \mathrm{C}$ selama 15 menit selama 3 kali dalam 1 minggu, kelompok kedua diberikan masase kaki selama 20 menit selama 3 kali dalam 1 minggu). Hasil perubahan tekanan darah kedua kelompok tersebut yang akan diperbandingkan.
Populasi dalam penelitian ini adalah orang yang memiliki riwayat penyakit hipertensi di wilayah kerja Puskesmas Suradita Kabupaten Tangerang sebanyak 57 orang. Sampel yang didapatkan peneliti sebesar 50 orang dengan metode purposive sampling yang dibagi menjadi 2 kelompok.

Pengumpulan data dilakukan dengan cara mengukur tekanan darah sebelum dan setelah diberikan intervensi pada masingmasing sampel menggunakan sphygmomanometer dan stetoskop. Selanjutnya data yang diperoleh ditulis pada lembar observasi pengukuran tekanan darah.

Untuk menganalisis perbedaan setiap kelompok digunakan Wilcoxon rank test karena distribusi data tidak normal, sedangkan untuk melihat perbedaan tekanan darah dengan hipertensi pada kedua kelompok digunakan uji statistik Mann Whitney dengan tingkat signifikansi $\mathrm{p} \leq 0.05$ dan tingkat kepercayaan yaitu 95\%. Uji statistik tersebut dilakukan dengan bantuan komputer. 


\section{HASIL PENELITIAN}

\section{Diagram 1}

Distribusi frekuensi jenis kelamin responden dengan hipertensi di wilayah kerja Puskesmas Suradita Kabupaten Tangerang $(\mathbf{n}=\mathbf{5 0})$.

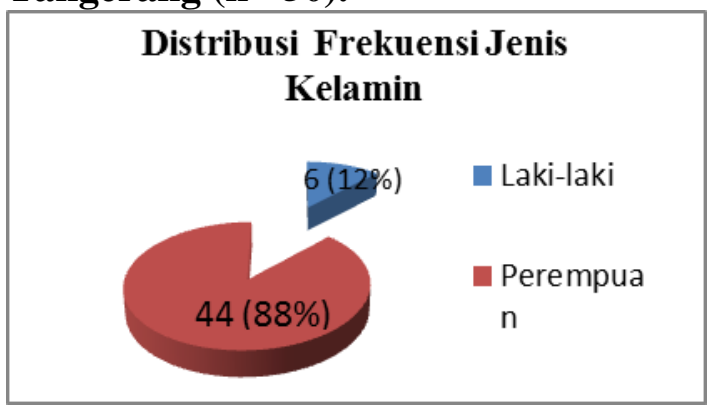

Berdasarkan gambar diagram pie 1 menunjukan bahwa sebagian besar responden berjenis kelamin perempuan sebanyak 44 responden (88\%), dan laki-laki 6 responden $(12 \%)$.

\section{Diagram 2}

Distribusi frekuensi Umur responden dengan hipertensi di wilayah kerja Puskesmas Suradita Kabupaten Tangerang $(\mathbf{n}=\mathbf{5 0})$.

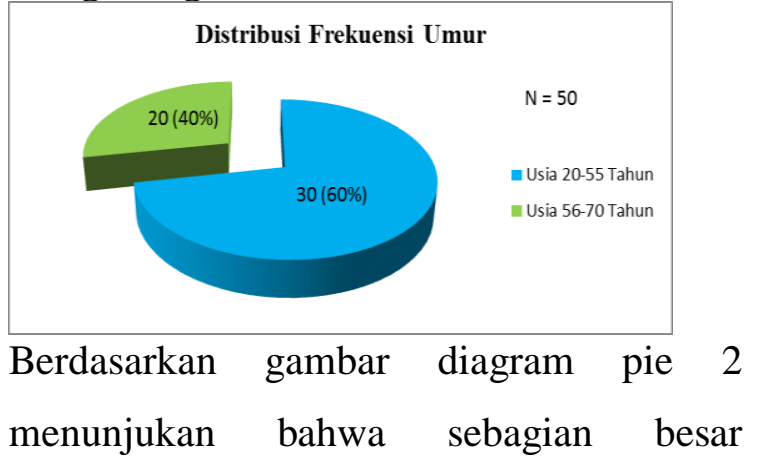

responden berusia 20-55 tahun sebanyak 30 responden (60\%), dan usia 56-70 tahun sebanyak 20 responden (40\%).
Distribusi $\begin{gathered}\text { Diagram } 3 \\ \text { frekuensi }\end{gathered}$ Pendidikan responden dengan hipertensi di wilayah kerja Puskesmas Suradita Kabupaten Tangerang $(\mathbf{n}=\mathbf{5 0})$.

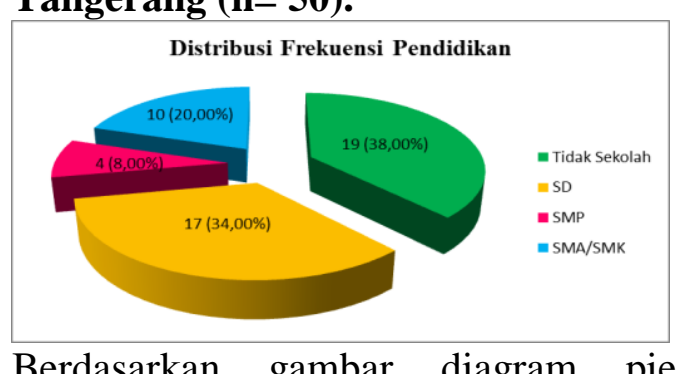

menunjukan bahwa sebagian besar responden tingkat pendidikan diproleh gambaran bahwa Tidak Sekolah sebanyak 19 responden (38\%), SD sebanyak 17 responden (34\%), SMA/SMK sebanyak 10 responden (20\%), SMP sebanyak 4 responden $(8 \%)$.

\section{Diagram 4}

Distribusi frekuensi Kelompok Perlakuan responden dengan hipertensi di wilayah kerja Puskesmas Suradita Kabupaten Tangerang $(n=50)$.

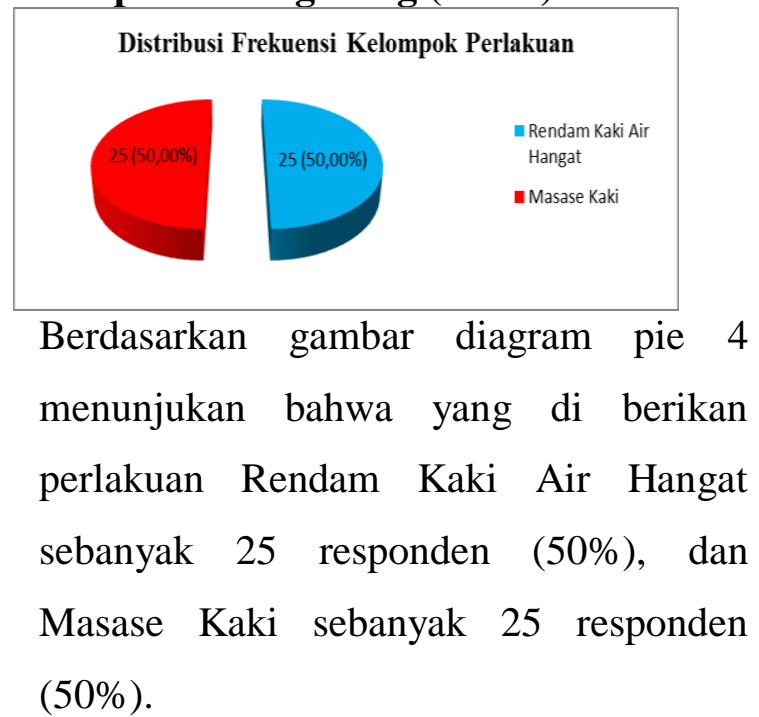




\section{Diagram 5}

Distribusi frekuensi Tekanan Darah Pre Rendam Kaki Air Hangat responden dengan hipertensi di wilayah kerja Puskesmas Suradita Kabupaten Tangerang $(n=25)$.

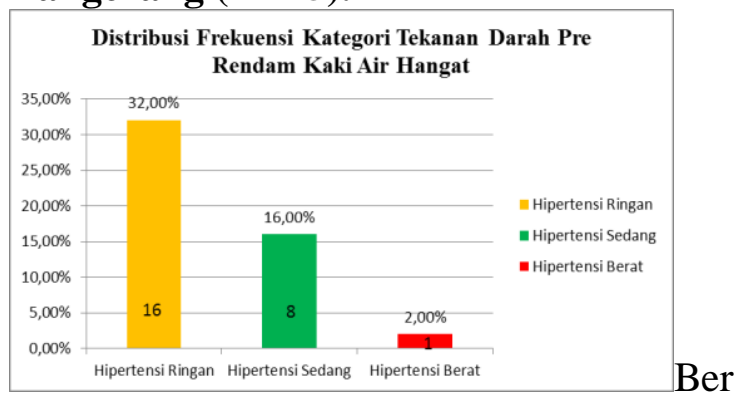

dasarkan gambar diagram batang 5.5 distribusi frekuensi kategori tekanan darah responden berdasarkan tekanan darah sebelum (Pre) dilakukan Rendam Kaki Air Hangat didapatkan : hipertensi ringan sebanyak 16 responden (32\%), hipertensi sedang sebanyak 8 responden $(16 \%)$ dan hipertensi berat sebanyak 1 responden $(2 \%)$.

\section{Diagram 6}

Distribusi frekuensi Tekanan Darah Post Rendam Kaki Air Hangat responden dengan hipertensi di wilayah kerja Puskesmas Suradita Kabupaten Tangerang $(n=25)$.

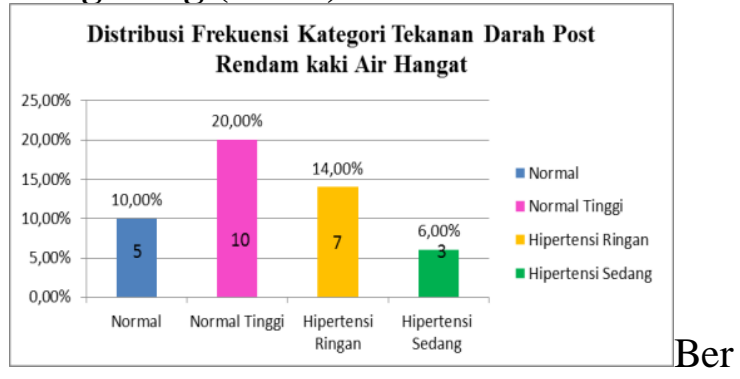

dasarkan gambar diagram batang 6 distribusi frekuensi kategori tekanan darah responden berdasarkan tekanan darah sesudah (Post) dilakukan Rendam Kaki Air
Hangat didapatkan : tekanan darah normal sebanyak 5 responden (10\%), normal tinggi sebanyak 10 responden (20\%), hipertensi ringan sebanyak 7 responden (14\%), dan hipertensi sedang sebanyak 3 responden $(6 \%)$.

\section{Diagram 7}

Distribusi frekuensi Tekanan Darah Pre Masase Kaki responden dengan hipertensi di wilayah kerja Puskesmas Suradita Kabupaten Tangerang $(n=25)$.

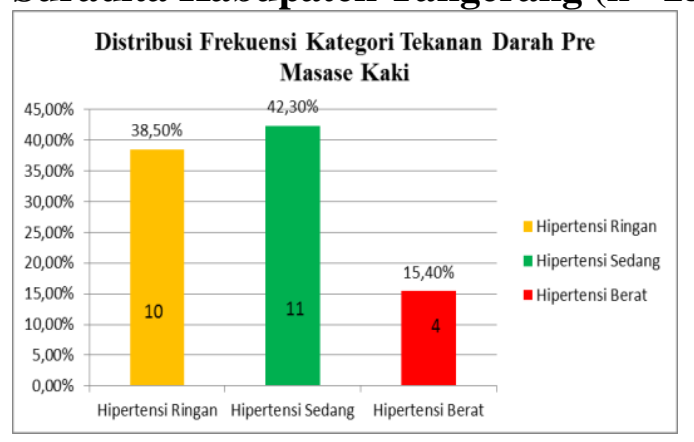

Berdasarkan gambar diagram batang 7 distribusi frekuensi kategori tekanan darah responden berdasarkan tekanan darah sebelum (pre) dilakukan masase Kaki didapatkan : hipertensi ringan sebanyak 10 responden $(38,5 \%)$, hipertensi sedang sebanyak 11 responden (42,3\%), dan hipertensi berat sebanyak 4 responden $(15,4 \%)$

\section{Diagram 8}

Distribusi frekuensi Tekanan Darah Post Masase Kaki responden dengan hipertensi di wilayah kerja Puskesmas Suradita Kabupaten Tangerang $(n=25)$. 


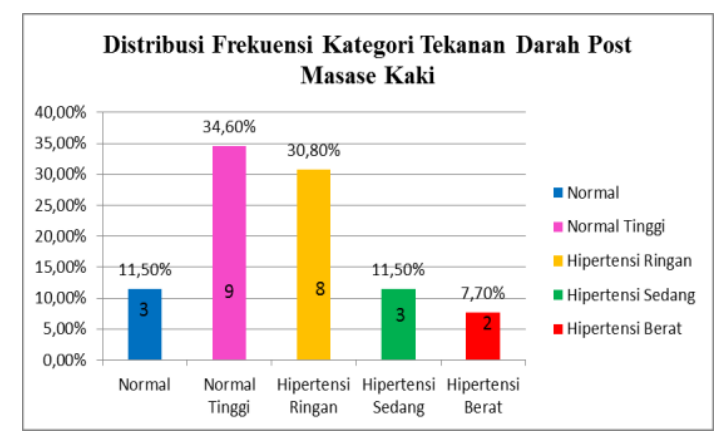

Berdasarkan gambar diagram batang 8 distribusi frekuensi kategori tekanan darah sesudah (Post) perlakuan masase kaki didapatkan : tekanan darah normal sebanyak 3 responden (11,5\%), normal tinggi sebanyak 9 responden $(34,6 \%)$, hipertensi ringan sebanyak 8 responden $(30,8 \%)$, hipertensi sedang sebanyak 3 responden $(11,5 \%)$, dan hipertensi berat sebanyak 2 responden $(7,7 \%)$.

\section{PEMBAHASAN}

Tekanan Darah Sebelum (Pre) dan Sesudah (Post) Rendam Kaki Air Hangat Terhadap Penurunan Tekanan Darah

Berdasarkan Teori (Perry \& Potter, 2010 dalam Badjun, 2015) terapi rendam kaki air hangat pada awal kontraksi, katup aorta dan katup semilunar belum terbuka. Untuk membuka katup aorta, tekanan di dalam ventrikel harus melebihi tekanan katup aorta. Keadaan dimana kontraksi ventrikel mulai terjadi sehingga dengan adanya pelebaran pembuluh darah, aliran darah akan lancar sehingga akan mudah mendorong darah masuk ke jantung sehingga menurunkan tekanan sistoliknya. Pada tekanan diastolik keadaan relaksasi ventrikular isovolemik saat ventrikel berelaksasi, tekanan di dalam ventrikel turun drastis, aliran darah lancar dengan adanya pelebaran pembuluh darah sehingga akan menurunkan tekanan diastolik.Maka dinyatakan ada hubungan yang signifikan antara terapi rendam kaki air hangat dengan penurunan tekanan darah sistolik dan diastolik.

Menurut peneliti Setelah diberikan perlakuan rendam kaki air hangat didalam baskom/ember yang diisi air hangat dengan suhu $39-40{ }^{\circ} \mathrm{C}$ dalam waktu 15 menit setiap pagi selama 1 minggu 3 kali berturut-turut, didapatkan hasil bahwa ada penurunan tekanan darah. Dimana air hangat memberikan dampak fisiologis dan terjadi perpindahan panas/hangat dari air hangat ke dalam tubuh akan menyebabkan pelebaran pembuluh darah dan penurunan ketegangan otot sehingga dapat melancarkan peredaran darah dan menurunkan tekanan darah.

Tekanan Darah Sebelum (Pre) dan Sesudah (Post) Masase Kaki Terhadap

\section{Penurunan Tekanan Darah}

Berdasarkan Teori Sari dkk, 2014 Teknik pemijatan berdampak terhadap lancarnya sirkulasi darah, menyeimbangkan aliran 
energi di dalam tubuh serta mengendurkan ketegangan otot. Meskipun teknik pemijatan tidak akan berdampak banyak pada penderita hipertensi berat, namun beberapa penelitian telah membuktikan bahwa masase dapat menurunkan tekanan darah pada penderita hipertensi ringan dan sedang.

Menurut peneliti Setelah diberikan perlakuan Masase Kaki dalam waktu 20 menit selama 1 minggu 3 kali secara berturut-turut terdapat penurunan tekanan darah karena responden mengatakan bahwa selama perlakuan pemijatan mereka merasa rilek dan nyaman, karena pemijatan pada titik tertentu dapat menghilangkan sumbatan dalam darah sehingga aliran darah dan energi di dalam tubuh kembali lancar dan dapat menurunkan tekanan darah.

\section{Perbandingan antara Rendam Kaki Air Hangat dan Masase Kaki Terhadap Penurunan Tekanan Darah}

Tabel 1. Perbandingan antara Perlakuan Rendam Kaki Air Hangat dan Masase

Kaki $(\mathbf{n}=50)$.

\begin{tabular}{cccc}
$\begin{array}{c}\text { Kelompok } \\
(\mathbf{N}=50)\end{array}$ & $\begin{array}{c}\text { Mean } \\
\text { Rank }\end{array}$ & $\begin{array}{c}\text { Sum of } \\
\text { Ranks }\end{array}$ & $\begin{array}{c}\boldsymbol{P} \\
\text { value }\end{array}$ \\
\hline $\begin{array}{c}\text { Rendam } \\
\text { kaki air } \\
\text { hangat }\end{array}$ & 25,06 & 626,50 & 0,831 \\
\cline { 1 - 2 } $\begin{array}{c}\text { Masase } \\
\text { kaki }\end{array}$ & 25,94 & 648,50 & \\
\hline
\end{tabular}

Berdasarkan tabel 1 menunjukan bahwa Perbandingan antara Perlakuan Rendam Kaki Air Hangat dan Masase Kaki, Analisis menggunakan uji statistik uji Mann-Whitney dengan tingkat kemaknaan $(\alpha=0,05)$ yang menunjukkan hasil Sig. (2tailed) atau $P$-value $=0,831$. Dengan $P$ value $=0,831 \geq \alpha=0,05$ maka Ha ditolak dan Ho diterima. Berdasarkan hasil analisis tersebut menunjukkan bahwa tidak ada perbandingan antara rendam kaki air hangat dan masase kaki terhadap penurunan tekanan darah pada pasien dengan hipertensi di Wilayah Kerja Puskesmas Suradita Kabupaten Tangerang.

Terapi komplementer non farmakologis dapat digunakan sebagai pelengkap untuk mendapatkan efek pengobatan farmakologis (obat anti hipertensi) yang lebih baik (Dalimartha, 2008). Beberapa penelitian telah membuktikan bahwa penatalaksanaan nonfarmakologis merupakan intervensi yang baik dilakukan pada setiap pengobatan hipertensi (Brunner \& Suddarth, 2002 dalam Hikayati, 2014).

\section{KESIMPULAN}

1. Tekanan Darah Sebelum (Pre) diberikan perlakuan Rendam Kaki Air Hangat didapatkan hasil: Hipertensi Ringan (32\%), Hipertensi Sedang (16\%), dan Hipertensi Berat (2\%). Dan 
Tekanan Darah sesudah (Post) diberikan Rendam Kaki Air Hangat didapatkan hasil : Tekanan Darah Normal (10\%), Normal Tinggi (20\%), Hipertensi Ringan (14\%), dan Hipertensi Sedang (6\%).

2. Tekanan Darah sebelum (pre) diberikan masase Kaki didapatkan hasil : Hipertensi Ringan (38,5\%), Hipertensi Sedang (42,3\%), Hipertensi Berat (15,4\%). Dan Tekanan Darah sesudah (Post) perlakuan masase kaki didapatkan : tekanan darah normal $(11,5 \%)$, normal tinggi $(34,6 \%)$, hipertensi ringan $(30,8 \%)$, hipertensi sedang $(11,5 \%)$, dan hipertensi berat $(7,7 \%)$.

3. tidak ada perbandingan antara perlakuan rendam kaki air hangat dan Masase Kaki terhadap penurunan tekanan darah, dengan Nilai $\mathrm{P}$ value $=$ 0,831 .

\section{SARAN}

1. Bagi Tempat Penelitian

Melihat hasil penelitian menunjukan bahwa kelompok perlakuan antara rendam kaki air hangat dan masase kaki kedua-duanya sama-sama bisa di aplikasikan dan diinformasikan kepada penderita hipertensi bahwa pengobatan non farmakologis rendam kaki air hangat dan masase kaki bisa untuk menurunkan tekanan darah dan dianjurkan dapat diaplikasikan dalam kehidupan sehari-hari.

2. Bagi Perawat

Untuk mengembangkan ilmu pengetahuan di program S1 Keperawatan dan perawat dapat memberikan penyuluhan kesehatan kepada penderita hipertensi tentang pengobatan non farmakologis yaitu dengan rendam kaki air hangat dan masase kaki dalam menurunkan tekanan darah dan diharapkan dapat diaplikasikan dalam kehidupan seharihari.

3. Bagi Peneliti yang lain

Bagi peneliti yang akan mengetahui lebih lanjut pada penelitian yang akan datang diharapkan menambahkan variabel variabel lain yang memang mendukung terhadap terjadinya hipertensi.

\section{DAFTAR PUSTAKA}

Batjun, Meikha Tari. 2015.Pengaruh Rendam Kaki Air Hangat Terhadap Penurunan Tekanan Darah Pada Lansia Penderita Hipertensi Di Wilayah Kerja Puskesmas Kecamatan Kebun Jeruk Jakarta Barat. diunduh pada hari sabtu tanggal 4 maret 2017 jam 14:14 wib. 
Hikayati, dkk.2014. Penatalaksaan Non

Farmakologis

Terapi

Komplementer SebagaiUpaya Untuk Mengatasi Dan Mencegah

Komplikasi Pada Penderita

Hipertensi Primer Di Kelurahan Indralaya Mulya Kabupaten Ogan Ilir. Diunduh pada hari rabu tanggal 31 mei 2017 jam 16:29 wib.

Ilkafah.2016. Perbedaan Penurunan

Tekanan Darah Lansia Dengan Obat Anti Hipertensi Dan Terapi Rendam Air Hangat Di Wilayah Kerja Puskesmas Antara Tamalanrea Makasar.diunduh pada hari rabu Tanggal 01 Februari 2017 jam 14:20 wib.

Masriadi.2016.Epidemiologi Penyakit Tidak Menular.Jakarta:TIM.

Nurgiwiati, E. 2015. Terapi Alternatif \& Komplementer dalam Bidang Keperawatan. Bogor : In Media.

Profil_kesehatan_kabupaten_tangerang_2 014.pdf diakses pada 01 februari 2017 jam 14:12 www.depkes.go.id

Riset Kesehatan Dasar (riskesdas) 2013.pdf diakses pada 06 februari 2017 jam 13:27 www.riskesdas.go.id

Sari, Dinny Wulan dkk. 2014. Perbedaan Tekanan Darah Sebelum Dan Sesudah Masase Kaki Dengan Menggunakan Minyak Esensial Lavender Terhadap Perempuan Prehipertensi Di Desa Karyawangi Kabupaten Bandung Barat.diunduh pada hari kamis tanggal 9 maret 2017 jam 17:52 wib. 